\title{
Current Status and Proposal of a Guideline for Manual Slide Review of Automated Complete Blood Cell Count and White Blood Cell Dfferential
}

\author{
Hee-Yeon Woo, M.D. ${ }^{1}$, Sang-Yong Shin, M.D. ${ }^{1}$, Hyosoon Park, M.D. ${ }^{1}$, Young Jae Kim, M.D. ${ }^{2}$, Hee-Jin Kim, M.D. ${ }^{3}$, \\ Young Kyung Lee, M.D. ${ }^{4}$, Seok-Lae Chae, M.D. ${ }^{5}$, Yoon Hwan Chang, M.D. ${ }^{6}$, Jong Rak Choi, M.D. ${ }^{7}$, \\ Kyungja Han, M.D. ${ }^{8}$, Sung Ran Cho, M.D. ${ }^{9}$, and Kye Chul Kwon, M.D. ${ }^{10}$
}

\begin{abstract}
Department of Laboratory Medicine', Kangbuk Samsung Hospital, Sungkyunkwan University School of Medicine, Seoul; Department of Laboratory Medicine'2, Samsung Changwon Hospital, Sungkyunkwan University School of Medicine, Changwon; Department of Laboratory Medicine ${ }^{3}$, Samsung Medical Center, Sungkyunkwan University School of Medicine, Seoul; Department of Laboratory Medicine4, Hallym University College of Medicine, Anyang; Department of Laboratory Medicine ${ }^{5}$, Dongguk University, Goyang; Department of Laboratory Medicine ${ }^{6}$, Korea Cancer Center Hospital, Seoul; Department of Laboratory Medicine ${ }^{7}$, Yonsei University College of Medicine, Seoul; Department of Laboratory Medicine ${ }^{8}$, The Catholic University of Korea, Seoul; Department of Laboratory Medicine ${ }^{9}$, Ajou University School of Medicine, Suwon; Department of Laboratory Medicine ${ }^{10}$, Chungnam National University College of Medicine, Daejeon, Korea
\end{abstract}

\begin{abstract}
Background : Manual slide review (MSR) is usually triggered by the results of automated hematolgy analyzers, but each laboaratory has different ciriteria for MSR. This study was carried out to investigate the current status of MSR criteria of automated complete blood cell count (CBC) and white blood cell (WBC) differential results and to propose a basic guideline for MSR.

Methods : Total 111 laboratories were surveyed regarding MSR using questionnaires. The questionnaire asked: kinds of automated hematology analyzers used and the presence of criteria triggering MSR in seven categories: 1) CBC results, 2) 5 differential WBC counts, 3) 3 differential WBC counts, 4) automated reticulocyte counts, 5) delta check, 6) instrument flags (or messages), 7) clinical information (wards or diseases). Based on the survey results, we determined basic and extended criteria for MSR. With these criteria, we consulted nine hematology experts to get a consensus.

Results : All 111 laboratories had their own MSR criteria. Among 111 laboratories, 98 (88.3\%) used more than three criteria for MSR including CBC results and 5-part WBC differential count results and 95 (85.6\%) had criteria of flags triggering MSR. For MSR criteria with numeric values, the 10th, 50th, and 90th percentiles of upper and lower threshold values were obtained. The basic guideline for MSR was made.

Conclusions : We proposed a basic guideline for MSR. This guideline would be helpful to hematology laboratories for their daily operation and providing more rapid and accurate $\mathrm{CBC}$ and WBC differential results. (Korean J Lab Med 2010;30:559-66)
\end{abstract}

Key Words : Hematology, Manual slide review, Guideline

\section{서 론}

Received: April 30, 2010

Revision received: July 1, 2010

Accepted: September 15, 2010

Corresponding author : Hyosoon Park, M.D.

Department of Laboratory Medicine, Kangbuk Samsung Hospital, Sungkyunkwan University School of Medicine, 108 Pyeong-dong, Jongno-gu, Seoul 110-746, Korea Tel : +82-2-2001-2368, Fax : +82-2-2001-2364 E-mail : hspcp@naver.com

*This work was supported by the "2008 Quality Improvement Research Program of the Laboratory Accreditation Committee, Korean Society of Laboratory Medicine (KSLM)".

ISSN 1598-6535 C The Korean Society for Laboratory Medicine
자동혈구분석기를 이용한 백혈구 수, 적혈구 수, 혈소판 수 측 정 및 백혈구감별계산 기능의 정확도와 임상적 유용성은 이미 여러 연구에서 확인되었고[1-4], 현재 사용되고 있는 자동혈구 분석기는 전혈구계산과 자동백혈구감별계산 기능 이외에도 flag 기능으로 다양한 정보를 제공하고 있다[5]. 비정상 세포의 확인, 비정상 전혈구계산 결과나 비정상 자동백혈구감별계산 결과의 확인을 위해서는 수기도말검토(manual slide review)가 여전 히 필요하다[4, 6]. 백혈구 감별계산의 표준 검사법(reference 
method)은 말초혈액 도말을 현미경으로 관찰하는 수기법이다 [7]. CAP survey [8]에 의하면 전혈구계산 검사가 의뢰된 검체 중 평균 $26.7 \%$ 의 검체에서 수기도말검토를 시행하는 것으로 보 고되었으며[8], 또한 각 검사실에서 어떤 수기도말검토 기준을 적용했는지에 따라 $5 \%$ 에서 $95 \%$ 의 다양한 수기도말검토 빈도 가 보고되어 공통 수기도말검토 기준의 필요성이 크다[9].

2005년에 미국, 캐나다 및 일부 유럽 국가 등이 공동 연구를 시행하여 수기도말검토 공통 기준을 제안하였다[9]. 그러나 국 내 각 검사실에서의 수기도말검토 시행 여부 및 기준에 대한 현 황조사가 이루어지지 않았다. 이에 저자들은 국내 검사실을 대 상으로 수기도말검토 시행 현황을 파악하고 의견을 모아 국내 현실에 맞는 수기도말검토 공통 기준을 제안하기 위하여 본 연 구를 수행하였다.

\section{재료 및 방법}

2009년에 대한진단검사의학회 검사실신임위원회 우수검사 실인증 프로그램에 등록되어 있는 전국의 236개 검사실에 수기 도말검토 시행 여부 및 기준을 묻는 설문 조사를 의뢰하여 111 검사실로부터 회신을 받았다. 설문조사 항목은 다음과 같았다: 1) 보유 자동혈구분석기 현황, 2) 전혈구계산 결과에 따른 수기 도말검토 기준 유무와 그 내용, 3) 5 분획 자동백혈구감별계산 결과에 따른 수기도말검토 기준 유무와 그 내용, 4) 3 분획 자동 백혈구감별계산 결과에 따른 수기도말검토 기준 유무와 그 내 용, 5) 자동망상적혈구 수 결과에 따른 수기도말검토 기준 유무 와 그 내용, 6) 델타검사에 따른 수기도말검토 기준 유무와 그 내용, 7) 임상 정보(환자 질병 혹은 병동)에 따른 수기도말검토 기준 유무와 그 내용, 8) flag에 따른 수기도말검토 기준 유무와 그 내용.

설문 조사 결과 50 개 이상의 검사실에서 적용하고 있는 수기 도말검토 수치 기준을 필수기준으로 선정하고 그 외의 권장기 준을 선정한 후, 이 기준에 대해 9 명의 진단검사의학과 전문의 에게 자문을 구하여 수기도말검토 필수기준 및 권장기준을 선 정하였다.

\section{결 과}

\section{1. 보유 자동혈구분석기 현황}

보유 자동혈구분석기 종류는 Table 1에 정리되어 있으며, 단 일 장비로 가장 많이 보유한 기종은 XE-2100 (Sysmex Co.,
Table 1. Distribution of automated hematology analyzers

\begin{tabular}{|c|c|c|}
\hline Company & Model & $\mathrm{N}$ of laboratory \\
\hline \multirow[t]{6}{*}{ Abbott Laboratories } & & 11 \\
\hline & Cell-Dyn Sapphire & 1 \\
\hline & Cell-Dyn 3700 & 5 \\
\hline & Cell-Dyn 3500 & 3 \\
\hline & Cell-Dyn 3000 & 1 \\
\hline & Cell-Dyn 1700 & 1 \\
\hline \multirow[t]{7}{*}{ Beckman-Coulter } & & 32 \\
\hline & LH1500 Series & 2 \\
\hline & LH-755 & 2 \\
\hline & LH-750 & 11 \\
\hline & Gen-S & 1 \\
\hline & $\mathrm{HMX}$ & 1 \\
\hline & STKS & 15 \\
\hline \multirow[t]{3}{*}{ Horiba-Abx diagnotics } & & 2 \\
\hline & Micros 60 & 1 \\
\hline & Pentra DX120 & 1 \\
\hline \multirow[t]{4}{*}{ Siemens/Bayer } & & 37 \\
\hline & ADVIA-2120 & 35 \\
\hline & ADVIA-60 & 1 \\
\hline & XS-1000I & 1 \\
\hline \multirow[t]{7}{*}{ Sysmex Co } & & 63 \\
\hline & $K X-21 N$ & 1 \\
\hline & K-4500 & 1 \\
\hline & SE-9000 & 1 \\
\hline & SF-3000 & 2 \\
\hline & $X E-2100$ & 49 \\
\hline & XT-1800I & 9 \\
\hline
\end{tabular}

Kobe, Japan)으로 49개 검사실에서 사용하고 있었다.

\section{2. 수기도말검토 기준}

설문 조사 회신을 보내 준 111 개 검사실 모두 자체 수기도말 검토 기준을 가지고 있었으며 적용 기준 항목 수에 따라 6 개 유 형으로 분류하였다(Table 2). 111 개 검사실 중 98 개(88.3\%) 검 사실에서 전혈구계산 결과와 5 분획 자동백혈구감별계산 결과 를 포함한 3 가지 이상의 기준을 사용하고 있었다.

\section{3. 전혈구계산 결과에 따른 수기도말검토 기준}

111 개 검사실 중 110 개(99.1\%) 검사실에서 전혈구계산 결과 에 따른 수기도말검토 기준을 정하여 사용하고 있었다(Table 3). 수기도말검토를 위한 혈색소( $\mathrm{Hb})$ 수치의 상한값과 하한값 의 중앙값(50th percentile)은 각각 $18 \mathrm{~g} / \mathrm{dL}$ 과 $7 \mathrm{~g} / \mathrm{dL}$ 이었다. 백혈구 수의 상한값과 하한값의 중앙값은 각각 $20 \times 10^{3} / \mu \mathrm{L}, 2$ $\times 10^{3} / \mu \mathrm{L}$ 이었으며, 혈소판 수의 상한값과 하한값의 중앙값은 각각 $700 \times 10^{3} / \mu \mathrm{L}$ 과 $100 \times 10^{3} / \mu \mathrm{L}$ 이었다. 
Table 2. Distribution of criteria for MSR according to the number of criteria used

\begin{tabular}{|c|c|c|c|c|c|c|c|c|}
\hline \multirow{2}{*}{$\begin{array}{l}N \text { of crite- } \\
\text { ria used }\end{array}$} & \multicolumn{7}{|c|}{ Criteria } & \multirow{2}{*}{$\begin{array}{l}\mathrm{N} \text { of labo- } \\
\text { ratory (\%) }\end{array}$} \\
\hline & CBC results & $\begin{array}{c}\text { 5-part WBC } \\
\text { differential count }\end{array}$ & Flags & $\begin{array}{l}\text { Delta } \\
\text { check }\end{array}$ & $\begin{array}{l}\text { Reticulocyte } \\
\text { count }\end{array}$ & $\begin{array}{c}\text { Clinical } \\
\text { information }\end{array}$ & $\begin{array}{c}\text { 3-part WBC } \\
\text { differential count }\end{array}$ & \\
\hline 6 & Y & Y & Y & Y & Y & Y & Y & $18(16.2)$ \\
\hline 5 & Y & Y & Y & \multicolumn{4}{|c|}{$\geq 2$ of 4 criteria } & $24(21.6)$ \\
\hline 4 & Y & Y & & \multicolumn{3}{|c|}{$\geq 2$ of 4 criteria } & $\mathrm{N}$ & 37 (33.3) \\
\hline 3 & Y & \multicolumn{5}{|c|}{$\geq 2$ of 5 criteria } & $\mathrm{N}$ & $19(17.1)$ \\
\hline 2 & Y & \multicolumn{5}{|c|}{$\geq 1$ of 5 criteria } & $\mathrm{N}$ & $11(9.9)$ \\
\hline 1 & $Y^{*}$ & $\mathrm{~N}$ & $Y^{*}$ & $N$ & $\mathrm{~N}$ & $\mathrm{~N}$ & N & $2(1.8)$ \\
\hline
\end{tabular}

* MSR is done when one of $\mathrm{CBC}$ results and flags is abnormal.

Abbreviations: MSR, manual slide review; CBC, complete blood cell count; WBC, white blood cell.

Table 3. Distribution of lower and upper threshold values for CBC parameters triggering MSR

\begin{tabular}{|c|c|c|c|c|}
\hline \multirow{2}{*}{ Criteria for MSR } & \multirow{2}{*}{$\mathrm{N}$ of laboratories* } & \multicolumn{3}{|c|}{ Values used according to the laboratory percentiles } \\
\hline & & 10th & 50th & 90th \\
\hline \multicolumn{5}{|l|}{ WBC count } \\
\hline Lower threshold value WBC count $\left(\times 10^{3} / \mu \mathrm{L}\right)$ & 105 & 1 & 2 & 3 \\
\hline Upper threshold value WBC count $\left(\times 10^{3} / \mu \mathrm{L}\right)$ & 106 & 15 & 20 & 50 \\
\hline \multicolumn{5}{|l|}{ Platelet count } \\
\hline Lower threshold value Platelet count $\left(\times 10^{3} / \mu \mathrm{L}\right)$ & 108 & 40 & 100 & 150 \\
\hline Upper threshold value Platelet count $\left(\times 10^{3} / \mu\llcorner)\right.$ & 96 & 500 & 700 & 1,000 \\
\hline \multicolumn{5}{|l|}{ Abnormal red cell indices } \\
\hline Lower threshold value RBC count $\left(\times 10^{6} / \mu \mathrm{L}\right)$ & 23 & 2.0 & 2.5 & 3.0 \\
\hline Upper threshold value $\mathrm{RBC}$ count $\left(\times 10^{6} / \mu \mathrm{L}\right)$ & 24 & 5.5 & 7.0 & 8.0 \\
\hline Lower threshold value $\mathrm{Hb}(\mathrm{g} / \mathrm{dL})$ & 89 & 5 & 7 & 8 \\
\hline Upper threshold value $\mathrm{Hb}$ (g/dL) & 70 & 17 & 18 & 20 \\
\hline Lower threshold value MCV (fL) & 52 & 60 & 70 & 78 \\
\hline Upper threshold value MCV (fL) & 58 & 105 & 110 & 120 \\
\hline Lower threshold value MCHC (g/dL) & 16 & 25 & 29 & 32 \\
\hline Upper threshold value MCHC (g/dL) & 22 & 35 & 37 & 40 \\
\hline Lower threshold value $\operatorname{Hct}(\%)$ & 6 & 15 & 20 & 26 \\
\hline Upper threshold value Hct (\%) & 6 & 50 & 55 & 60 \\
\hline Lower threshold value RDW (\%) & 5 & 9.0 & 11.0 & 11.5 \\
\hline Upper threshold value RDW (\%) & 7 & 14.5 & 17.0 & 18.0 \\
\hline \multicolumn{5}{|l|}{$\mathrm{NRBC}^{\dagger}$} \\
\hline Lower threshold value (\%) & 0 & - & - & - \\
\hline Upper threshold value (\%) & 35 & 1 & 2 & 10 \\
\hline
\end{tabular}

*110 (99.1\%) out of 111 laboratories had CBC values triggering MSR; 'Some hematology analyzers reported NRBC \%, while others reported only the presence of NRBC.

Abbreviations: CBC, complete blood cell count; MSR, manual slide review; WBC, white blood cell; RBC, red blood cell; MCV, mean cell volume; MCHC, mean cell hemoglobin concentration; RDW, red blood cell distribution width; NRBC, nucleated red blood cell; LUC, large unstained cell.

\section{5 분획 자동백혈구감별계산 결과에 따른 수기도말검토 기준}

111 개 검사실 중 104 개(93.7\%) 검사실에서 5 분획 자동백혈구 감별계산 결과에 따른 수기도말검토 기준을 정하여 사용하고 있었다(Table 4). 검사실에 따라서 각 분획의 상한값과 하한값 의 절대 수치 혹은 백분율(\%)을 사용하고 있었다. 중성구 백분 율과 절대 수치의 하한값의 중앙값은 각각 $20 \%$ 와 $1.0 \times 10^{3} / \mu \mathrm{L}$
이었고, 상한값의 중앙값은 $81.0 \%, 10.0 \times 10^{3} / \mu \mathrm{L}$ 이었다. 림프 구 백분율과 절대 수치의 하한값과 상한값의 중앙값은 각각 $10 \%$, $0.8 \times 10^{3} / \mu \mathrm{L}$ 와 $60.0 \%, 4.0 \times 10^{3} / \mu \mathrm{L}$ 이었다. 호산구와 호염기구 에 대한 기준이 있는 경우 대부분 상한값에 대한 기준만이 있었 다. 유핵적혈구의 경우 일부 자동혈구분석기에서는 그 존재만 이 flag로 보고되지만 일부 분석기에서는 \%로 보고되었다. 
Table 4. Distribution of lower and upper threshold values for 5part WBC differential counts triggering MSR

\begin{tabular}{|c|c|c|c|c|}
\hline \multirow[t]{2}{*}{ Criteria for MSR } & \multirow[t]{2}{*}{$\begin{array}{c}\mathrm{N} \text { of labo- } \\
\text { ratories* }\end{array}$} & \multicolumn{3}{|c|}{$\begin{array}{c}\text { Values used } \\
\text { according to the } \\
\text { laboratory percentiles }\end{array}$} \\
\hline & & 10th & 50th & 90th \\
\hline \multicolumn{5}{|l|}{ Neutrophil } \\
\hline Lower threshold value $\left(\times 10^{3} / \mu \mathrm{L}\right)$ & 12 & 0.5 & 1.0 & 1.5 \\
\hline Upper threshold value $\left(\times 10^{3} / \mu \mathrm{L}\right)$ & 11 & 4.0 & 10.0 & 20.0 \\
\hline Lower threshold value (\%) & 32 & 10 & 20 & 37 \\
\hline Upper threshold value (\%) & 53 & 78.0 & 81.0 & 90.0 \\
\hline \multicolumn{5}{|l|}{ Lymphocyte } \\
\hline Lower threshold value $\left(\times 10^{3} / \mu \mathrm{L}\right)$ & 6 & 0.1 & 0.8 & 1.5 \\
\hline Upper threshold value $\left(\times 10^{3} / \mu \mathrm{L}\right)$ & 13 & 3.7 & 4.0 & 5.0 \\
\hline Lower threshold value (\%) & 27 & 5.0 & 10.0 & 20.0 \\
\hline Upper threshold value (\%) & 89 & 50.0 & 60.0 & 70.0 \\
\hline \multicolumn{5}{|l|}{ Monocyte } \\
\hline Lower threshold value $\left(\times 10^{3} / \mu \mathrm{L}\right)$ & 0 & - & - & - \\
\hline Upper threshold value $\left(\times 10^{3} / \mu \mathrm{L}\right)$ & 14 & 0.7 & 1.0 & 8.0 \\
\hline Lower threshold value (\%) & 4 & 1.0 & 2.0 & 10.0 \\
\hline Upper threshold value (\%) & 96 & 10.0 & 20.0 & 25.0 \\
\hline \multicolumn{5}{|l|}{ Eosinophil } \\
\hline Lower threshold value $\left(\times 10^{3} / \mu \mathrm{L}\right)$ & 0 & - & - & - \\
\hline Upper threshold value $\left(\times 10^{3} / \mu \mathrm{L}\right)$ & 13 & 0.5 & 0.7 & 2.0 \\
\hline Lower threshold value (\%) & 1 & - & 0 & - \\
\hline Upper threshold value (\%) & 90 & 10.0 & 20.0 & 25.0 \\
\hline \multicolumn{5}{|l|}{ Basophil } \\
\hline Lower threshold value $\left(\times 10^{3} / \mu \mathrm{L}\right)$ & 0 & - & - & - \\
\hline Upper threshold value $\left(\times 10^{3} / \mu \mathrm{L}\right)$ & 13 & 0.2 & 0.3 & 2.0 \\
\hline Lower threshold value (\%) & 1 & - & 0 & - \\
\hline Upper threshold value (\%) & 87 & 2.0 & 3.0 & 5.0 \\
\hline \multicolumn{5}{|l|}{ LUC } \\
\hline Lower threshold value (\%) & 0 & - & - & - \\
\hline Upper threshold value (\%) & 38 & 4.0 & 5.0 & 10.0 \\
\hline Band form (\%) & 1 & - & 10 & - \\
\hline
\end{tabular}

*104 (93.7\%) out of 111 laboratories had 5-part WBC differential count values triggering MSR.

Abbreviations: WBC, white blood cell; MSR, manual slide review; LUC, large unstained cell.

\section{Flag에 따른 수기도말검토 기준}

111 개 검사실 중 95개(85.6\%) 검사실에서 flag에 따른 수기 도말검토 기준을 정하여 사용하고 있었다(Table 5). 20 개 검사 실에서 flag 종류에 관계없이 모든 flag에 대하여 수기도말검토 를 시행하고 있었다. Flag 중 모세포(blast)가 표시될 때 수기도 말검토를 시행하는 검사실이 59 개로 가장 많았으며, 혈소판 응 집(platelet clumping), 비정형림프구(atypical lymphocyte), 미성숙과립구(immature granulocyte), 유핵적혈구(nucleated $\mathrm{RBC}$ ), 좌방이동(left shift), 적혈구응집(RBC agglutination), 거대혈소판(large platelet), 골수세포형과산화효소 결핍 (myeloperoxidase deficiency) 등의 flag 순으로 수기도말검
Table 5. Distribution of flags triggering MSR

\begin{tabular}{lc}
\hline Flags & N of laboratories $(\%)^{*}$ \\
\hline All flags & $20(18.0)$ \\
Blast & $59(53.1)$ \\
PLT clump & $55(49.5)$ \\
Atypical lymphocyte & $53(47.7)$ \\
Immature granulocyte & $51(45.9)$ \\
NRBC & $50(45.0)$ \\
Left shift & $30(27.0)$ \\
RBC agglutination & $16(14.4)$ \\
Large PLT & $15(13.5)$ \\
MPO deficiency & $8(7.2)$ \\
Abnormal scatter gram & $6(5.4)$ \\
Cellular interference & $5(4.5)$ \\
Verify differential count & $5(4.5)$ \\
LUC & $4(3.6)$ \\
RBC lyse resistance & $3(2.7)$ \\
\hline
\end{tabular}

*95 (85.6\%) out of 111 laboratories had criteria of flags triggering MSR. Abbreviations: MSR, manual slide review; PLT, platelet; NRBC, nucleated red blood cell; RBC, red blood cell; MPO, myeloperoxidase; LUC, large unstained cell.

Table 6. Distribution of lower and upper threshold values for automated reticulocyte count triggering MSR

\begin{tabular}{lrrrrr}
\hline Criteria for MSR & $\begin{array}{c}\text { N of } \\
\text { labora- } \\
\text { tories }\end{array}$ & \multicolumn{3}{c}{$\begin{array}{c}\text { Values used accord- } \\
\text { ing to the laboratory } \\
\text { percentiles }\end{array}$} \\
\cline { 3 - 6 } & & 10th & 50 th & 90 th \\
\hline $\begin{array}{l}\text { Reticulocyte count (absolute number) } \\
\text { Lower threshold value }\left(\times 10^{3} / \mu \mathrm{L}\right)\end{array}$ & 0 & - & - & - \\
$\begin{array}{l}\text { Upper threshold value }\left(\times 10^{3} / \mu \mathrm{L}\right) \\
\text { Reticulocyte count }(\%)\end{array}$ & 2 & 95.0 & - & 200.0 \\
Lower threshold value $(\%)$ & 8 & 0.1 & 0.3 & 0.5 \\
Upper threshold value $(\%)$ & 56 & 4.0 & 5.0 & 10.0 \\
\hline
\end{tabular}

*56 (50.5\%) out of 111 laboratories had reticulocyte count values triggering MSR.

Abbreviation: MSR, manual slide review.

토를 시행하는 것으로 조사되었다. 그 외에 16 개 검사실에서는 비정상 적혈구 분포(abnormal RBC distribution), 비정상 혈 소판 분포(abnormal platelet distribution) 등의 flag도 수기 도말검토 기준으로 사용하고 있었다.

\section{6. 자동 망상적혈구 수 결과에 따른 수기도말검토 기준}

111 개 검사실 중 56 개 $(50.5 \%)$ 검사실에서 자동 망상적혈구 수 결과에 따른 수기도말검토 기준을 정하여 사용하고 있었다 (Table 6). 52개 검사실은 단순히 도말을 검토할 뿐만 아니라 수기로 망상적혈구 계수도 시행하고 있었다. 대부분의 검사실 에서 상한값 기준만을 가지고 있었고 상한값의 중앙값은 $5 \%$ 이 
Table 7. Distribution of delta check values triggering MSR

\begin{tabular}{|c|c|c|c|c|}
\hline \multirow[t]{2}{*}{ Criteria for MSR } & \multirow{2}{*}{$\begin{array}{l}\mathrm{N} \text { of } \\
\text { labora- } \\
\text { tories }\end{array}$} & \multicolumn{3}{|c|}{$\begin{array}{l}\text { Delta check values } \\
\text { used according to the } \\
\text { laboratory percentiles }\end{array}$} \\
\hline & & 10th & 50th & 90th \\
\hline \multicolumn{5}{|l|}{$\mathrm{Hb}$} \\
\hline Absolute value (g/dL) & 3 & 3.0 & 3.0 & 3.5 \\
\hline$\%$ value & 21 & 20 & 30 & 100 \\
\hline \multicolumn{5}{|l|}{ RBC count } \\
\hline Absolute value $\left(\times 10^{6} / \mu \mathrm{L}\right)$ & 1 & - & 1.5 & - \\
\hline$\%$ value & 9 & 20 & 30 & 100 \\
\hline \multicolumn{5}{|l|}{ Hct } \\
\hline Absolute value (\%) & 0 & - & - & - \\
\hline$\%$ value & 12 & 20 & 20 & 50 \\
\hline \multicolumn{5}{|l|}{ WBC } \\
\hline Absolute value $\left(\times 10^{3} / \mu \mathrm{L}\right)$ & 3 & 1.0 & 2.0 & 5.0 \\
\hline$\%$ value & 24 & 40 & 45 & 75 \\
\hline \multicolumn{5}{|l|}{ PLT } \\
\hline Absolute value $\left(\times 10^{3} / \mu \mathrm{L}\right)$ & 6 & 100 & 100 & 150 \\
\hline$\%$ value & 24 & 30 & 50 & 75 \\
\hline \multicolumn{5}{|l|}{ Neutrophil } \\
\hline Absolute value $\left(\times 10^{3} / \mu \mathrm{L}\right)$ & 0 & - & - & - \\
\hline$\%$ value & 9 & 20 & 40 & 50 \\
\hline Lymphocyte & & - & & \\
\hline Absolute value $\left(\times 10^{3} / \mu \mathrm{L}\right)$ & 0 & - & - & - \\
\hline$\%$ value & 11 & 30 & 50 & 70 \\
\hline \multicolumn{5}{|l|}{ Monocyte } \\
\hline Absolute value $\left(\times 10^{3} / \mu \mathrm{L}\right)$ & 0 & - & - & - \\
\hline$\%$ value & 9 & 10 & 30 & 100 \\
\hline \multicolumn{5}{|l|}{ Eosinophil } \\
\hline Absolute value & 0 & - & - & - \\
\hline$\%$ value & 9 & 5 & 30 & 100 \\
\hline \multicolumn{5}{|l|}{ Basophil } \\
\hline Absolute value $\left(\times 10^{3} / \mu \mathrm{L}\right)$ & 0 & - & - & - \\
\hline$\%$ value & 9 & 20 & 50 & 200 \\
\hline \multicolumn{5}{|l|}{ MCV } \\
\hline Absolute value (fL) & 1 & - & 5 & - \\
\hline$\%$ value & 1 & - & 10 & - \\
\hline
\end{tabular}

*51 (45.9\%) out of 111 laboratories answered that they were performing MSR according to the delta check results, but only 30 submitted specific delta check values triggering MSR.

Abbreviations: MSR, manual slide review; RBC, red blood cell; WBC, white blood cell; PLT, platelet; MCV, mean cell volume.

었다(Table 6).

\section{7. 델타검사에 따른 수기도말검토 기준}

111 개 검사실 중 51 개(45.9\%) 검사실에서 델타검사에 따른 수기도말검토 기준을 정하여 사용하고 있었다(Table 7). 51개 검사실 중 47 검사실에서 수치 기준을 사용한다고 답하였으나 30 검사실만이 자세한 수치 기준을 답하였다. 4 개 검사실은 구 체적 수치 기준 없이 주관적으로 이전 결과와 차이가 많이 나는
Table 8. Presence of MSR criteria according to clinical information (wards)

\begin{tabular}{lc}
\hline Wards & N of laboratories (\%) \\
\hline Newborn unit \& Hemato-oncology ward & $17(15.3)$ \\
Newborn unit only & $12(10.8)$ \\
Hemato-oncology ward only & $7(6.3)$ \\
None & $75(67.6)$ \\
Total & $111(100)$ \\
\hline
\end{tabular}

Abbreviation: MSR, manual slide review.

경우 수기도말검토를 시행한다고 답하였다(Table 7).

\section{8. 임상 정보에 따른 수기도말검토 기준 유무}

111 개 검사실 중 36 개(32.4\%) 검사실에서 질병이나 병동과 같은 임상 정보에 따른 특수 수기도말검토 기준을 정하여 사용 한다고 답하였으나 대부분 구체적인 기준을 언급하지 않았다 (Table 8).

\section{3 분획 자동백혈구감별계산 결과에 따른 수기도말검토 기준}

111 개 검사실 중 3 개(2.7\%)의 검사실에서 3 분획 자동백혈구 감별계산 결과에 따른 수기도말검토 기준을 정하여 사용하고 있었으며, 3 개 검사실 모두 5 분획 자동백혈구감별계산 결과에 따른 수기도말검토 기준도 동시에 적용하고 있었다. 3 개 검사 실 모두 림프구 백분율이 $50 \%$ 이상, 단구 백분율이 두 검사실 은 $20 \%$ 이상, 한 개 검사실은 $15 \%$ 이상을 기준으로 수기도말검 토를 시행하고 있었으며, 중성구에 대한 수기도말검토 기준은 기술하지 않았다.

\section{0. 수기도말검토 필수기준 및 권장기준의 최종 선정}

설문조사를 바탕으로 선정한 필수기준과 권장기준에 대하여 9 명의 진단검사의학과 전문의의 자문을 구한 결과, $60 \%$ 이상의 전문의가 필수기준 및 권장기준이 적합하다고 답하였다. 수치 기준의 경우 가장 많은 전문의가 적합하다고 답한 수치로 기준 을 결정하였는데, 호염기구를 제외한 모든 항목에서 50th percentile 수치가 기준으로 정해졌으며, 호염기구는 90th percentile 수치가 기준으로 정해졌다(Table 9). 그 외 제안된 사항 은 토의 후에 기준에 적용하였으며, 일부 장비에서만 적용 가능 한 제안은 반영하지 않았다. 
Table 9. A proposed guideline for MSR

\begin{tabular}{lc}
\hline Criteria & Values \\
\hline Basic criteria & \\
Hb & \\
$\quad$ Lower threshold value $(\mathrm{g} / \mathrm{dL})$ & 7.0 \\
$\quad$ Upper threshold value $(\mathrm{g} / \mathrm{dL})$ & 18.0 \\
Platelet count & \\
$\quad$ Lower threshold value $\left(\times 10^{3} / \mu \mathrm{L}\right)$ & 100.0 \\
$\quad$ Upper threshold value $\left(\times 10^{3} / \mu \mathrm{L}\right)$ & 700.0 \\
WBC count & \\
$\quad$ Lower threshold value $\left(\times 10^{3} / \mu \mathrm{L}\right)$ & 2.0 \\
$\quad$ Upper threshold value $\left(\times 10^{3} / \mu \mathrm{L}\right)$ & 20.0 \\
Neutrophil & \\
$\quad$ Upper threshold value $(\%)$ & 81.0 \\
Lymphocyte & \\
$\quad$ Upper threshold value $(\%)$ & 60.0 \\
Monocyte & \\
$\quad$ Upper threshold value $(\%)$ & 20.0 \\
Eosinophil \\
$\quad$ Upper threshold value $(\%)$ & \\
Basophil & \\
$\quad$ Upper threshold value $(\%)$ & \\
Reticulocyte & \\
$\quad$ Upper threshold value $(\%)$ & \\
Blast flag & \\
PLT clump flag (with low PLT count*) & \\
Extended criteria & \\
Atypical lymphocyte/variant lymphocyte flag & \\
NRBC (\% or flag) & \\
$\quad$ Upper threshold value $(\%)$ & Positive \\
Delta check \\
Clinical information (wards or diseases) \\
\hline
\end{tabular}

${ }^{*}<100.0 \times 10^{3} / \mu \mathrm{L}$.

Abbreviations: MSR, manual slide review; WBC, white blood cell; PLT, platelet; NRBC, nucleated red blood cell.

\section{고 찰}

국내 검사실을 대상으로 수기도말검토 시행 현황을 파악하고 의견을 모아 국내 현실에 맞는 수기도말검토 공통 기준을 선정 하여 제안하고자 본 연구를 수행하였다.

자동혈구분석기의 성능이 향상됨에 따라 염색된 말초혈액 도 말 검토의 역할은 자동혈구분석기 결과를 확인하고 추가적인 정보를 제공하거나 자동혈구분석기의 분석 능력을 벗어나는 부 분을 보완하는 것으로 바뀌었다[9, 10]. 그러나 수기도말검토는 시간이 많이 소요되고 추가 비용이 들며 숙련된 전문 인력이 시 행해야 하는 등의 단점이 있어 검사실에 큰 부담이 된다. 그러 나 수기도말검토 시행 후에 $35.7 \%$ 의 검체에서 검사결과를 수정 할 필요가 있는 새로운 정보를 알게 되었다고 보고되어[8] 수기 도말검토의 필요성은 무시될 수 없다. 그러므로 검사결과의 질 은 유지시키면서 슬라이드 재검률을 최소한으로 낮추어 검사실
의 효율성을 증가시킬 필요성이 증가하고 있으며, 각 검사실은 자동혈구분석기 결과를 바탕으로 적절한 수기도말검토 기준을 만들어 적용시키도록 권장되고 있다[8].

본 연구에서 조사가 이루어진 111 개 검사실 모두 자체 수기도 말검토 기준을 가지고 있었으며, $88.3 \%$ 의 검사실에서 전혈구계 산 결과 및 5 분획 자동백혈구감별계산 결과를 포함한 3 개 이상 의 기준을 적용하여 수기도말검토를 시행하고 있었다. 또한 최 근에 개발된 자동혈구분석기의 경우 5 분획 백혈구감별계산 기 능과 함께 확장 감별계산 기능에 의해 미성숙 혹은 비정형 세포, 모세포, 비정형림프구, 유핵적혈구 등의 비정상 세포에 대한 flag도 제공함에 따라 각 검사실에서도 이러한 추가 기능을 이 용한 수기도말검토도 시행하고 있는 것으로 조사되었다. 2006 년 Novis 등[8]의 연구에서도 수기도말검토를 시행하는 가장 큰 이유는 백혈구, 적혈구, 혈소판의 수치 이상과 함께 장비의 flag 보고이었다. 다른 몇몇 연구에서도 전혈구계산 결과와 5 분 획 자동백혈구감별계산 결과 및 flag를 수기도말검토 기준으로 제시하고 있다[9-11].

본 연구에서 95 개(85.6\%) 검사실에서 flag에 대한 수기도말 검토 기준을 사용하고 있었는데 이 결과는 기존 연구[8]에서 보 고된 $80.7 \%$ 보다 약간 높았다. 자동혈구분석기에서 제공하는 여 러 flag는 장비 기종에 따라 혹은 비정상 세포의 종류 및 그 양 에 따라 민감도, 특이도 등이 다르며 위양성이나 위음성 결과가 존재하는데 일반적으로 모세포나 유핵적혈구가 비정형림프구/ 변이(variant) 림프구와 좌방이동/미성숙과립구보다 분석기에 의해 더 정확하게 검출되는 것으로 보고되었다 $[1,3,4,12,13]$. 또한 이러한 flag가 보고되지 않더라도 혈액질환이 의심되는 경 우 수기도말검토를 시행해야 한다고 보고되었다[4]. 따라서 flag 를 수기도말검토 기준으로 정할 경우 각 검사실에서 사용하고 있는 자동혈구분석기의 특성을 고려할 뿐만 아니라 비정상 세 포가 발견될 확률이 많아서 flag의 중요성이 높은 환자군도 고 려하여 기준을 정할 필요가 있다[14-16]. 이전 연구[8]에 의하 면 나이, 진단명, 입원 여부, 병동(예를 들면 신생아실, 중환자 실 등) 등의 환자군의 특성에 따른 수기도말검토 기준도 조사되 었다. 본 연구에서도 111 개 검사실 중 36 개(32.4\%) 검사실에서 신생아실이나 혈액종양내과 검체에 대해 특수 수기도말검토 기 준을 적용하고 있는 것으로 조사되었다.

본 연구에서 조사된 전혈구계산 결과에 따른 수기도말검토 기준의 중앙값(50th percentile 값)을 살펴보면 총 백혈구 수의 상한값은 $20.0 \times 10^{3} / \mu \mathrm{L}$, 하한값은 $2.0 \times 10^{3} / \mu \mathrm{L}$ 으로 조사되었 다. 또한 혈소판 수의 상한값과 하한값은 각각 $700 \times 10^{3} / \mu \mathrm{L}$, $100 \times 10^{3} / \mu \mathrm{L}$ 이었고 혈색소는 각각 $18.0 \mathrm{~g} / \mathrm{dL}, 7.0 \mathrm{~g} / \mathrm{dL}$ 로 조 
사되었다. 이 결과는 기존 연구[10] 결과(총 백혈구 수, $20.1 \times$ $10^{3} / \mu \mathrm{L}, 2.5 \times 10^{3} / \mu \mathrm{L}$; 혈소판 수, $800 \times 10^{3} / \mu \mathrm{L}, 80.0 \times 10^{3} / \mu \mathrm{L}$; $\mathrm{Hb}, 18.0 \mathrm{~g} / \mathrm{dL}, 8.0 \mathrm{~g} / \mathrm{dL})$ 와 비교적 일치하였다. 5 분획 백혈구 감별계산 결과에 따른 수기도말검토 기준과 자동 망상적혈구 수에 따른 수기도말검토 기준의 경우 대부분의 검사실에서 상 한값을 기준으로 이용하고 있었다. 델타검사에 따른 수기도말 검토 기준을 살펴보면 111 개 검사실 중에서 51 개(45.9\%) 검사실 이 기준을 가지고 있는 것으로 조사되었지만 구체적인 수치를 표기한 검사실은 30 개 검사실에 불과하여 수치 기준의 정확한 분포를 알 수 없었다. 그러나 수기도말검토를 위한 델타 값은 각 검사실의 분석기 종류와 생리학적 변화를 고려하여 정하여야 한다고 권고되고 있어[9] 각 검사실은 나름대로의 기준을 정해 야 할 것이며 이에 본 연구 결과가 참고가 될 것으로 생각된다.

수기도말검토 공통 기준 제시를 위한 연구로 15 개 검사실이 참여하여 2005년에 그 기준이 보고되었다[4]. 이 연구에서는 83 개의 수기도말검토 기준을 미리 선정하고 15 개 검사실에서 13,298 개의 혈액 검체에 이 기준을 실제로 적용해 본 후 최종적 으로 41 개의 기준을 선정하였다. 선정된 수기도말검토 기준은 전혈구계산 결과, 5 분획 백혈구감별계산 결과, flag, 델타검사 등의 검사 정보와 함께 나이, 진단명, 처음 시행한 검사인지 추 적 검사인지 등의 임상 정보에 따라서 세분화되어 있다. 또한 단순히 도말을 관찰, 검토할 것인지 수기법으로 백혈구 감별계 산을 할 것인지도 구분하였다. 따라서 본 연구와 같이 단순히 각 검사실의 수기도말검토 기준을 종합, 분석하여 수기도말검 토 기준을 선정한 것보다 임상적 유용성이 더 클 것으로 생각된 다. 그러므로 향후에는 본 연구에서 제안된 수기도말검토 기준 을 검사실에서 일정 기간 동안 실제로 적용해 본 후에 부족한 점을 보완하는 것이 필요하다. 또한 1,2 차 병원 검사실은 필수 기준만 적용하고 3 차 병원은 권장기준까지 적용하자는 제안이 있었는데, 수기도말검토의 빈도가 병원 규모에 비례하여 증가 하기 때문에[8] 이에 대한 추가 연구도 이루어져야 할 것으로 생 각된다.

본 연구를 통해 각 검사실에서 시행하고 있는 수기도말검토 기준을 바탕으로 하는 공통 수기도말검토 기준을 제안하며, 이 기준이 신속, 정확한 혈액검사 결과 보고와 효율적인 검사실 운 영에 도움이 될 것으로 생각된다.

\section{요 약}

배경 : 수기도말검토(manual slide review)는 일반적으로 자동혈구분석기의 결과에 근거하여 이루어지나 검사실마다 수
기도말검토 기준이 다르다. 본 연구는 전혈구계산과 백혈구감 별계산 결과에 따른 수기도말검토 기준의 국내 현황을 조사하고 기본적인 수기도말검토 기준을 제안하기 위하여 시행되었다.

방법 : 총 111 개의 검사실을 대상으로 수기도말검토 관련 설 문조사를 시행하였다. 설문 내용은 보유 자동혈구분석기 현황 및 다음과 같은 7 가지 수기도말검토 기준 유무에 대한 문항으로 구성되었다: 1) 전혈구계산 결과, 2) 5 분획 백혈구감별계산 결 과, 3) 3 분획 백혈구감별계산 결과, 4) 자동 망상적혈구 수, 5) 델타 검사(delta check), 6) 장비의 flag (또는 message), 7) 임 상 정보(병동 또는 질병). 설문조사 결과를 바탕으로 수기도말 검토에 대한 기본 기준과 확장 기준을 정하였으며, 이를 9 명의 전문가에게 검토 의뢰하여 합의안을 마련하였다.

결과 : 조사된 111 개 검사실 모두 자체 수기도말검토 기준을 가지고 있었다. 111 개 검사실 중 98 개 검사실(88.3\%)에서 전혈 구계산 결과와 5 분획 백혈구감별계산 결과를 포함한 3 가지 이 상의 기준을 사용하고 있었으며, 95 개 검사실(85.6\%)에서는 flag에 따른 기준을 사용하고 있었다. 수기도말검토 수치 기준 의 경우 상한값과 하한값의 10th, 50th, 90th percentile 값을 구하였다. 수기도말검토 기본 기준을 선정하였다.

결론 : 저자들은 수기도말검토를 위한 기본 기준을 제안하였 다. 이 기준은 각 진단혈액 검사실에서 보다 신속하고 정확한 전 혈구계산과 백혈구감별계산 결과를 제공하는 데 유용할 것이다.

\section{감 사}

설문조사에 회신하여 주신 111 개 검사실 담당자들께 감사드 립니다.

\section{참고문헌}

1. Kang SH, Kim HK, Ham CK, Lee DS, Cho HI. Comparison of four hematology analyzers, CELL-DYN Sapphire, ADVIA 120, Coulter LH 750, and Sysmex XE-2100, in terms of clinical usefulness. Int J Lab Hematol 2008;30:480-6.

2. Stroop DM, Triplett RC, Perrotta G, Roberts LP, Schramm RC, Comer $\mathrm{K}$, et al. Comparison of the Abbott Cell Dyn 3000-SL and the Coulter-STKS hematology analyzers. Ann Clin Lab Sci 1994;24:250-8.

3. Bentley SA, Johnson A, Bishop CA. A parallel evaluation of four automated hematology analyzers. Am J Clin Pathol 1993;100:62632.

4. Thalhammer-Scherrer R, Knöbl P, Korninger L, Schwarzinger I. 
Automated five-part white blood cell differential counts. Efficiency of software-generated white blood cell suspect flags of the hematology analyzers Sysmex SE-9000, Sysmex NE-8000, and Coulter STKS. Arch Pathol Lab Med 1997;121:573-7.

5. Buttarello M and Plebani M. Automated blood cell counts: state of the art. Am J Clin Pathol 2008;130:104-16.

6. Bain BJ. Diagnosis from the blood smear. N Engl J Med 2005;353: 498-507.

7. Clinical and Laboratory Standards Institute. Reference leukocyte (WBC) differential count (proportional) and evaluation of instrumental methods: approved standard. CLSI document H20-A2. 2nd ed. Wayne, PA: Clinical and laboratory standards institute, 2007:163.

8. Novis DA, Walsh M, Wilkinson D, St Louis M, Ben-Ezra J. Laboratory productivity and the rate of manual peripheral blood smear review: a College of American Pathologists Q-Probes study of 95,141 complete blood count determinations performed in 263 institutions. Arch Pathol Lab Med 2006;130:596-601.

9. Barnes PW, McFadden SL, Machin SJ, Simson E. International consensus group for hematology. The international consensus group for hematology review: suggested criteria for action following automated CBC and WBC differential analysis. Lab Hematol 2005;11:8390.

10. Lantis KL, Harris RJ, Davis G, Renner N, Finn WG. Elimination of instrument-driven reflex manual differential leukocyte counts. Opti- mization of manual blood smear review criteria in a high-volume automated hematology laboratory. Am J Clin Pathol 2003;119:65662.

11. Hyun BH, Gulati GL, Ashton JK. Differential leukocyte count: manual or automated, what should it be? Yonsei Med J 1991;32:283-91.

12. Swaim WR. Laboratory and clinical evaluation of white blood cell differential counts. Comparison of the Coulter VCS, Technicon H1, and 800-cell manual method. Am J Clin Pathol 1991;95:381-8.

13. Gulati G, Behling E, Kocher W, Schwarting R. An evaluation of the performance of Sysmex XE-2100 in enumerating nucleated red cells in peripheral blood. Arch Pathol Lab Med 2007;131:1077-83.

14. Lee YK, Kang HJ, Kim YM, Won CY, Cho HC. Evaluation of the ABX Pentra DX 120 for the detection of immature cells in peripheral blood. J Lab Med Qual Assur 2008;30:249-58. (이영경, 강희정, 김영 민, 원철연, 조현찬. 말초혈액의 미성숙세포 진단에 있어 자동혈구분석기 ABX Pentra DX 120의 유용성 평가. 임상검사와 정도관리 2008;30:24958.)

15. Ruzicka K, Veitl M, Thalhammer-Scherrer R, Schwarzinger I. The new hematology analyzer Sysmex XE-2100: performance evaluation of a novel white blood cell differential technology. Arch Pathol Lab Med 2001;125:391-6.

16. Peterson P, Blomberg DJ, Rabinovitch A, Cornbleet PJ. Physician review of the peripheral blood smear: when and why. An opinion. Lab Hematol 2001;7:175-9. 